\title{
Challenges of a Scholarly Biography of Primate Stefan Wyszyński
}

Słowa kluczowe: prymas Stefan Wyszyński, biografia, wyzwania badawcze, nauczanie społeczne, rzeczywistość społeczno-polityczna.

Keywords: Primate Stefan Wyszyński, biography, research challenges, social teaching, socio-political reality.

\section{ABSTRACT}

This study outlines the challenges faced by authors who might undertake in the future the task of writing a full scholarly biography of Cardinal Stefan Wyszyński. The author of this paper analyzes the state of research to date and evaluates the existing literature on the subject. The following two sections deal with challenges regarding source material and interpretive challenges in describing diverse areas of the life and scope of the Primate of the Millennium's activities. The paper focuses on the period of Wyszyński's service as a primate, as it seems that in-depth research on the earlier stages of Stefan Wyszyński's life could be an arduous task to conduct.

\section{Introduction}

lthough many years have passed since the death of Cardinal Stefan Wy1 szyński, and a vast amount of literature has since been written, we do not 
yet have a complete biography of the Primate of the Millennium ${ }^{1}$. The biographical studies currently available are incomplete for various reasons ${ }^{2}$ and primarily due to a lack of sources or interpretive shortfalls, which will be broadly referred to in this paper. A significant advantage for an author of the Primate's future biographies (as this task seems to be too overwhelming for just one researcher) is many detailed studies on various periods of the Cardinal's life and specific issues from his priestly and then primate ministry. Significantly, researchers from almost all fields of humanities - social and theological sciences - have studied Wyszyński; historians and theologians understandably come to the fore, but there are also analyses prepared by sociologists, philosophers, lawyers, educators, political scientists (to name a few). I refer to some of the existing detailed studies in the analysis below, indicating which ones are relevant to the description of the life and activity of this key figure for Polish history.

Researchers' challenge is the extent of the literature of the subject and the sheer number of archival sources that need to be examined (or verified, following the trail of many previous researchers), including archival resources currently unavailable or very difficult to access. It seems equally difficult to analyze the entire intellectual material and the legacy of Cardinal Wyszynski. In the Archives of the Institute of Primate Stefan Cardinal Wyszyński in Choszczówka alone, there are around twelve to thirteen thousand speeches and homilies of the Cardinal (of which he authorized only a part).

${ }^{1}$ Summary of the work of Cardinal Wyszyński and the publication on this subject can be found in M. P. Romaniuk, Prymas Tysiąclecia w stowie pisanym. Bibliografia życia, twórczości i posługi Kardynała Stefana Wyszyńskiego 1921-2017, vol.1-2, Warszawa 2018. The supplementary character (with works published between the year 2018 and 2020) is a bibliography in the book by R. Łatka, B. Mackiewicz, D. Zamiatała, Prymas Stefan Wyszyński. Biografia, Warszawa 2020. Currently, in Biblioteka Narodowa [the National Library], the search engine indicates 4003 publications regarding Cardinal Wyszyński (or his authorship), including 705 books. https://katalogi.bn.org.pl/discovery/search?query=any,contains,stefan\%20wyszy\%C5\%84ski\&tab=LibraryCatalog\&vid=48OMNIS_NLOP:48OMNIS_NLOP\&lang=pl\&offset=0 (6.07.2020).

2 The most important biographical works were written by P. Raina, Stefan kardynat Wyszyński prymas Polski, vol. 1-3, London 1979-1988; P. Raina, Stefan Kardynat Wyszyński. Prymas Tysiąclecia], vol. 1-5, Warszawa 2016; A. Micewski, Kardynał Wyszyński. Prymas i mą̇ stanu, Paris 1982; M. P. Romaniuk, Życie, twórczość i posługa Stefana Kardynata Wyszyńskiego Prymasa Tysiaclecia, vol. 1-4, Warszawa 1994-2002; E. Czaczkowska, Kardynał Wyszyński. Biografia, Kraków 2013. 
Attempts to interpret the life and activities of the Primate are equally demanding. So far, most attempts (especially the biographical ones) look at him as a person through the prism of the role played in Poland's socio-political reality under communist rule ${ }^{3}$. Cardinal Wyszynski is perceived as statesman and interrex, and his role as pastor and leader of the Church seems to be secondary at best, while it should be precisely the opposite.

In the following considerations, I try to present the challenges that biographers of Cardinal Wyszynski are facing comprehensively. I explicate and evaluate the literature on the subject. Also, I outline what in-depth archival queries should be carried out and investigate a particularly important issue that is key to interpretations that can be used in preparing a complete biography of the Primate of the Millennium's life and activities.

\section{The current state of research and evaluation of existing literature on the subject}

While describing the state of research on the biographies of Cardinal Wyszyński, I focus on the most important publications and those which, in my opinion, bring new information about his life and activities concerning earlier biographical attempts. The existing literature of the subject starts with the earliest and perhaps least known biography of Cardinal Wyszyński from the late sixties, namely Stefan Cardinal Wyszyński. Biography in photographs ${ }^{4}$. It was arranged by a friend of the Primate, Fr. Zdzisław Peszkowski ${ }^{5}$, and published

${ }^{3}$ There is no complete monograph on the political stance of Cardinal Wyszyński to the Polish People's Republic as a state. There is: L. Mażewski, Prymas Stefan Kardynat Wyszyński wobec Polski po 1944/1945 r. Elementy analizy ustrojoznawczej i geopolitycznej, Warszawa 2020, but it cannot be considered a monograph. The most interesting although only partial considerations on this subject were presented by P. Skibiński, Do jakiego stopnia PRL byt państwem polskim? Ocena prymasa Wyszyńskiego, [in:] Prymas Stefan Wyszyński a Niepodległa. Naród - patriotyzm - państwo w myśli i nauczaniu Prymasa Tysiąclecia, eds. E. Czaczkowska, R. Łatka, Warszawa 2019, pp. 77-87. I have also partially presented issue this in several articles referred to later in this study).

${ }^{4}$ Stefan Kardynat Wyszyński. Biografia w fotografiach, Orchard Lake 1969.

${ }^{5}$ This cleric was also a tireless chaplain of 'rodziny katyńskie' [the "Katyn Families"] and, of those murdered in the East. G. Łęcicki, Harcerz, ułan, kapłan. Ks. Zdzisław Peszkowski, Warszawa 2012. 
in Orchard Lake (so-called American Częstochowa) in 1969 for the Polish diaspora in the United States. It contains basic biographical information about the hero of this publication and an extraordinary iconography, including photos from different periods of the life of Cardinal Wyszynski ${ }^{6}$. Books by Peter Raina and Andrzej Micewski constitute further biographical studies on Cardinal Wyszyński.

The first of those two authors, Peter Raina, published in 1979-1988 a three-volume work - Cardinal Stefan Wyszyński, the Primate of Poland. This work was then systematically expanded and complemented over the following years. The next version was published in twenty volumes between 1993 and $2012^{7}$; the content is no different from its last edition (five extensive volumes) released in $2016^{8}$. The nature of Raina's publication is difficult to categorize precisely. The most appropriate term for this publication is, in my opinion, source extracts with some commentary (usually not very extensive). His works contain documents from three archival sources - the secretariat of the Primate of Poland, the archives of the Secretary of the Polish Episcopate, Bishop Bronisław Dąbrowski (which are in part currently located in the Warsaw Archdiocesan Archive and the Archives of the Secretariat of the Polish Episcopal Conference) and the Archiwum Akt Nowych [Archives of New Records] and mainly in the units of the KC PZPR and the Office for Religious Denominations). For the researchers of modern history and biographers of Cardinal Wyszyński, the most valuable were excerpts from Pro memoria written by the Cardinal. However, until the complete review of the manuscripts and typescripts of Wyszyński's journals (gathered in the Archives of the Archdiocese of Gniezno $^{9}$ ) was carried out, historians were not aware of how selective in his choice of sources Peter Raina was. Often, the India-born historian did not finish sentences, nor did he include quotations that could certainly contradict his thesis on the life and activities of Cardinal Wyszynski. There-

${ }^{6}$ Only the albums released in Poland after 2000 contained an extensive photo documentation, see: Droga życia. Stefan Kardynał Wyszyński, Bydgoszcz 2001; R. Łatka, B. Mackiewicz, D. Zamiatała, Kardynał Stefan Wyszyński...

7 P. Raina, Kardynał Wyszyński, vol. 1-14, Warszawa, 1993-2006; vol. 15-20, Warszawa-Bielsko Biała 2012.

${ }^{8}$ P. Raina, Stefan Kardynał Wyszyński. Prymas Tysiaclecia, vol. 1-5...

9 The copy of same can also be found in the Archdiocesan Archive of Warsaw. 
fore, researchers of the Catholic Church's history face the task of thoroughly verifying Raina's work to correct the mistakes and source manipulations that he may have committed. Peter Raina's books regarding the Primate should be considered a rough material of complementary nature to archival sources' readings. In no case can they be considered a biography (needless to say, that this is not entirely a scholarly publication ${ }^{10}$ ).

A far more valuable publication, biographical in its character, is a study by Andrzej Micewski, Kardynat Wyszyński, Prymas i mąż stanu [Cardinal Wyszyński, a primate and statesman], published in Paris in 1982. Its subsequent and, only to some extent supplemented version, was released in $2000^{11}$. Like Peter Raina, the author had access to the records of Cardinal Wyszynski. Unlike the Raina, however, Micewski used them to interpret the Primate's activities, not just to publish them with a modest commentary ${ }^{12}$. This author's publication is undoubtedly a valuable contribution, especially in describing the Primate's role in the socio-political sphere. Andrzej Micewski convincingly proved that Cardinal Wyszyński played a crucial role in the continuance of the Catholic Church in Poland and the growth of its authority in Polish society and in a significant influence on the history of Poland that he had during the communist rule. It is wise, in my opinion, to agree with the statement Micewski made at the beginning of his deliberations - "The question may arise as to why the greatest Pole of our generation was a clergyman, not a politician. After all, Wyszyński never wanted to be a political person and always distanced himself from practicing politics. However, unintentionally he became not only a "prince of the church" but also a Polish statesman. Even his communist opponents had to acknowledge this"13. Although Micewski rightly points out that the most important thing for the Primate was his pastoral mission in the

${ }^{10}$ It needs to be noted that none of the books by Peter Raina had any scholarly review.

11 A. Micewski, Stefan Kardynat Wyszyński (1901-1981), Warszawa 2000.

12 At this point, the question should be asked how much of the assessment made by Micewski was influenced by his secret service cooperation with SB (especially when looking at the role of the so-called progressive Catholic circles). This remark, of course, refers in greater extent to another book of the same author Wspótrzadzić czy nie klamać. PAX i Znak w Polsce 1945-1976, Paris 1978. For more on the relationship of Micewski's and secret security apparatus, see: A. Friszke, Sekrety Andrzeja Micewskiego, "Tygodnik Powszechny" 21 August 2006.

13 A. Micewski, Kardynał Wyszyński..., vol. 1, p. 5. 
Church, in his reflections, he does not give too much attention to this aspect of Cardinal's activities and focuses mainly on Wyszyński's role in the sociopolitical sphere.

A four-volume chronological timeline developed by Marian Piotr Romaniuk is a crucial publication for all biographers of the Primate of the Millennium ${ }^{14}$. It is a reliable study, although not without some errors or omissions, resulting from a lack of access to all sources, such as the notes Pro memoria by Cardinal Wyszyński or documentation from the collection of the Secretariat of Primate of Poland gathered in the Archdiocesan Archive of Warsaw. Nevertheless, thanks to Romaniuk's documentary work, we can find basic information about the life and activities of Stefan Wyszyński (including some information impossible to find in other sources). It is vital to appreciate the enormous body of documented work that the author has done. The question is whether the new updated edition (including literature on the subject, which had been published since the release of Romaniuk's work) should be further developed or not.

The latest attempt to present the biography of Cardinal Wyszyński is a study by Ewa Czaczkowska. The work of this Warsaw historian aspires to be a comprehensive biography of the Primate. At first glance, however, one can see that the author is far from exhausting the subject ${ }^{15}$. It is due to several fundamental reasons. First, the author did not access many essential archival sources. It is particularly apparent in how little use of records from the resources of the Secretariat of the Primate of Poland (the Archdiocesan Archives of Warsaw) the author has made. Czaczkowska limited herself only to the minutes of the Commission/Main Council's meetings and only one [sic!] document produced by the Primate - "The political situation in Poland and the normalization of relations between the state and the Church. Points to be discussed at RG [Main Council], 4 May 1972, Jasna Góra"16. What is lacking is

14 M. P. Romaniuk, Życie, twórczość i posługa Stefana Kardynała Wyszyńskiego...

15 The author is aware of this, and in 2020 she released another publication concerning the biography of the Primate. However, one can look in vain for some new information about life and activities of Cardinal Wyszynski, see: E. Czaczkowska, Prymas Wyszyński.Wiara, nadzieja, miłość, Krakow 2020.

16 The full content of this document, together with a comprehensive commentary in: R. Łatka, "Normalizacja" relacji państwo-Kościót w latach siedemdziesiątych XX wieku 
an analysis of materials from the plenary meetings of the Episcopate and the documentation on the situation in individual dioceses, their relations with the authorities, or the correspondence of Primate Wyszyński (both with clergy and laity). For her work, Czaczkowska also looked over a dozen case files from the Institute of National Remembrance Archives. However, her search was limited to the most obvious clues: the operational documentation containing the Primate's name in the title ${ }^{17}$. Czaczkowska also failed to reach for the anti-church materials of Polish security apparatus structures such as periodical reports, surveillance of the Metropolitan Curia of Warsaw, files of close associates of the Primate (secretaries of the Episcopate - Bp. Zygmunt Choromański and Bp. Bronisław Dąbrowski, to name but a few) or materials from files with personal work sources of information used to 'de-conspire' the Cardinal ${ }^{18}$. The situation is not much better when it comes to the author's use of AIPSKW (the Archive of the Institute of Primate Cardinal Stefan Wyszyński) resources. However, in the bibliography, there were references to the collective works of Cardinal Wyszyński, but actually, the author rarely made use of those ${ }^{19}$. As regards the Primate's approach to state-church relations, Czaczkowska did not use the documentation of the Office for Religious Denominations and KC PZPR regarding the Cardinal himself and the approach of the authorities to bishops and clergy.

Apart from missing references in Czaczkowska's book, there are also severe flaws in interpretation. In the first place, the author focuses on Cardi-

z perspektywy Prymasa Stefana Wyszyńskiego - nieznany dokument z Sekretariatu Prymasa Polski, "Pamięć i Sprawiedliwość" 2018, no. 2, pp. 531-546.

17 The only exceptions are the files of the secret service work of Sr. Maria Leonia Graczyk and Fr. Stanislaw Skorodecki, fellow prisoners of the Primate during internment and, documentation on Fr. Wojciech Turowski.

18 On categories of archival sources from the IPN Archives useful in conducting research on history of the Catholic Church in the Polish People's Republic and the role of Primate Wyszyński see: R. Eatka, Problemy metodologiczne w prowadzeniu badan na temat historii Kościoła katolickiego w Polsce "ludowej". Przegląd badań, postulaty badawcze, "Dzieje Najnowsze" 2016, no. 1, pp. 221-233.

19 One can consider the best use of this material only when describing the role of Card. Wyszyński at the Second Vatican Council. Ewa Czaczkowska is also the author of a separate study on this subject, Prymas Polski Stefan kardynał Wyszyński na Soborze Watykańskim II, [in:] Studia Soborowe vol. 1: Historia i nauczanie Vaticanum II, ed. M. Białkowski, Toruń 2013, pp. 143-168. 
nal Wyszyński's approach to socio-political issues, while the fundamental aspect of a biography of the Primate, which was his service to the Church, is only marginal in Czaczkowska's study. In this extensive book of more than 700 pages, we can find only a few pages of reflections on pastoral programs of the Primate of the Millennium or how he managed the Province of Gniezno and Province of Warsaw. The activities of the Cardinal in the western and northern provinces have also been referred to quite marginally. Czaczkowska also did not give too much attention to the Polish Episcopate's internal relations between the most important hierarchs in the Polish Church (she only discussed in more detail the relationships between Cardinal Wyszyński and Cardinal Karol Wojtyła). Another drawback of the book is its narrative style it is journalistic rather than scholarly. It is evident in both descriptive and interpretive aspects. In the descriptive realm, the archival sources are not confronted with one other. The author does not have historical skills and does not try to verify previous researchers' findings, does not wonder which of them were wrong and which ones can be considered accurate and convincing. Ewa Czaczkowska also draws far-reaching conclusions about the different aspects of the Primate's life and activities based on tenuous grounds, often on a single source, without verifying her theses. In terms of assessing her findings, Czaczkowska is not detached while making her assessments. It is apparent, for example, in the assessment of Cardinal Wyszyński's relations with the so-called progressive Catholics, such as PAX, "Znak", "Tygodnik Powszechny", or "Więzi". Instead of trying to assess them critically, we are dealing here with a promising approach of one of the parties to this relationship (that is, broadly understood as a group of laypeople with a leftist outlook, except for PAX) and attempts to justify their actions (which always resulted from good intentions).

The latest biographical study on the life and activities of Cardinal Wyszyński is a synthetic work by myself, Beata Mackiewicz, and Dominik Zamiatała ${ }^{20}$. I have no intention of being a judge in my case and assessing how effectively we have achieved the research objectives set out in the book's introduction. I will only point out that the research intention was to present the biography of Stefan Wyszyński in its broad perspective, that is, both his strictly pastoral

20 R. Łatka, B. Mackiewicz, D. Zamiatała, Prymas Stefan Wyszyński... 
activities and also his efforts in the socio-political sphere, in the most concise way possible (this publication can also be a good starting point for any future comprehensive scholarly biography of the Primate of the Millennium).

Describing the state of research on Stefan Wyszyński, one should pay attention to the many detailed studies on selected periods of his life and various aspects of his activities (especially as a primate). I do not list them here in detail, but I focus on the most important publications (including those less known for various reasons).

The childhood and adolescence of Stefan Wyszyński is the least researched topic so far. Only one separate work was created ${ }^{21}$ on this subject, although some information in this regard can be found in the comprehensive biographical studies ${ }^{22}$. When researching for example, a period of time in Włocławek, studies at KUL (Catholic University in Lublin) and World War II, one should pay particular attention to publications (listed in order of their scholarly value for the Primate's biographers): Piotr Nicki ${ }^{23}$, Antoni Poniński ${ }^{24}$, Małgorzata Laskowska $^{25}$, Jerzy Bagrowicz ${ }^{26}$, Witold Kujawski ${ }^{27}$. It is also worth looking into two reference editions containing the publications of Fr. Wyszyński from this period of his life ${ }^{28}$. As for the period of his Lublin episcopacy, there are

${ }^{21}$ R. Czarnowski, U kolebki życia Prymasa Tysiąclecia. W setną rocznicę urodzin i chrztu Stugi Bożego Kardynała Stefana Wyszyńskiego, Łomża 2001.

22 For example, see: R. Łatka, B. Mackiewicz, D. Zamiatała, Prymas Stefan Wyszyński..., pp. 14-17.

23 P. Nitecki, Ksiądz Stefan Wyszyński jako profesor katolickiej nauki społecznej we Włocławku (1931-1939), "Studia Prymasowskie" 2007, vol. 1; idem, Włocławskie dzieje księdza Stefana Wyszyńskiego 1917-1946, Warszawa 2008; idem, Ksiądz Stefan Wyszyński w perspektywie rozpoznania komunizmu, "Studia Prymasowskie" 2009, vol. 3.

24 A. Poninski, Realista i prorok. Zarys poglądów ks. Stefana Wyszyńskiego na komunizm i socjalizm, “Ateneum Kapłańskie” 2001, no. 136.

25 M. Laskowska, Praca dziennikarska i redaktorska ks. Stefana Wyszyńskiego w latach 1924-1946, "Studia Prymasowskie" 2009, vol. 3.

26 J. Bagrowicz, "Najmilszy trud mego życia”. Ksiądz Stefan Wyszyński jako redaktor i publicysta, "Ateneum Kapłańskie” 2001, vol. 553, no. 3.

27 W. Kujawski, Szkic włocławskich dziejów Stefana Wyszyńskiego, “Ateneum Kapłańskie" 2001, vol. 553, no. 3.

28 S. Wyszyński, Katolicka nauka społeczna. Wybór artykułów z "Ateneum Kapłańskiego" z lat 1929-1946, Włocławek 2001; idem, Początki nauczania społecznego (1934-1939), Warszawa 2001. 
two complementing books by Piotr Nitecki ${ }^{29}$, and Bolesław Pylak ${ }^{30}$. Recently, an influential publication has also been released covering this period of Stefan Wyszyński's life ${ }^{31}$.

The life and activities of Cardinal Wyszyński during his primate period was selectively described in a huge number of publications. When writing a new biography of Wyszyński one should, in my opinion, pay special attention to publications of the following authors (listed in alphabetical order) ${ }^{32}$ : Czesław Bartnik $^{33}$, Michał Białkawski ${ }^{34}$, Adam Dziurok ${ }^{35}$, Jerzy Eisler ${ }^{36}$, Ryszard Ficek $^{37}$, Andrzej Grajewski ${ }^{38}$, Józef Krukowski ${ }^{39}$, Jerzy Lewandowski ${ }^{40}$, Rafał

${ }^{29}$ P. Nitecki, "Wiem jak godnq stolicę obejmuję w dziedzictwie”. Biskup Stefan Wyszyński pasterz Kościoła lubelskiego, Lublin 2012.

30 B. Pylak, Stefan Wyszyński Biskup Lubelski, Lublin 2000.

31 M. Leszczyński (ed.), Protokoły wizytacji kanonicznych przeprowadzonych przez biskupa lubelskiego Stefana Wyszyńskiego w parafiach na terenie obecnej diecezji zamojsko-lubaczowskiej 1946-1948, Warszawa 2020.

32 I do not list the earlier outlined biographical papers.

${ }_{33}$ Cz. S. Bartnik, Chrześcijańska nauka o narodzie według prymasa Wyszyńskiego, Rome 1982; Cz. S. Bartnik (ed.), Polska teologia narodu, Lublin 1988.

34 M. Białkowski, Protokoły Konferencji polskich ojców soborowych 1962-1965, Lublin 2019.

35 A. Dziurok, Prymas Stefan Wyszyński wobec władz komunistycznych w latach 1949-1956, "Studia Prymasowskie" 2012, vol. 6.

36 J. Eisler, Stefan Wyszyński i Władysław Gomułka - dwie wizje Polski, [in:] Pojednanie i polityka. Polsko-niemieckie inicjatywy pojednania w latach sześćdziesiątych XX wieku a polityka odprężenia, eds. F. Boll, W. J. Wysocki, K. Zimmer, Warszawa 2010.

37 R. Ficek, Zaangażowanie chrześcijan w życie wspótczesne w kontekście nauczania kardynała Stefana Wyszyńskiego Prymasa Polski, Lublin 2020.

38 A. Grajewski, Jesień Prymasów. Kardynałowie Mindszenty i Wyszyński wobec przełomu 1956 roku, "Studia Prymasowskie" 2012, vol. 6; idem, Kardynałowie Stefan Wyszyński i Agostino Casaroli - dwie osobowości i dwie koncepcje polityki wschodniej Watykanu, "Studia Prymasowskie" 2009, vol. 3.

39 J. Krukowski, Uprawnienia nadzwyczajne kard. Stefana Wyszyńskiego, Prymasa Polski, wobec zagrożeń ze strony reżimu komunistycznego, "Studia Prymasowskie" 2001, vol. 5 .

40 J. Lewandowski, Naród w nauczaniu kardynała Stefana Wyszyńskiego, Warszawa 1989. 
Łatka ${ }^{41}$, Robert Nęcki ${ }^{42}$, Bartłomiej Noszczak ${ }^{43}$, Kazimierz Śmigel ${ }^{44}$, Wiesław Jan Wysocki ${ }^{45}$, Zygmunt Zielinski ${ }^{46}$, and Jan Żaryn ${ }^{47}$. The findings of these authors contribute a lot to our knowledge of different aspects of the life and activities of Cardinal Wyszyński.

${ }^{41}$ R. Łatka, Czy prymasa Wyszyńskiego można określać mianem realisty politycznego?, [in:] Realizm polityczny, ed. R. Łatka, "Politeja" 2013, no. 25, pp. 201-212; idem, "Bronić Solidarność przed wkraczaniem na tereny polityczne”. Prymas Stefan Wyszyński wobec Solidarności, [in:] Stefan Wyszyński wobec opozycji i oporu społecznego 1945-1981, ed. E. Czaczkowska, Warszawa 2018; idem, Koniec odwilży w relacjach państwo-Kościót (1957-1958) z perspektywy prymasa Stefana Wyszyńskiego, [in:] Księga pamiatkowa dla bp. Edwarda Frankowskiego, eds. M. Krzysztofiński, J. Wołczański, Rzeszów 2018; idem, Prymas Stefan Wyszyński wobec zagrożenia interwencją sowiecka 1980-1981, "Studia z Dziejów Rosji i Europy Środkowo-Wschodniej” 2018, vol. 1; idem, Prymas Wyszyński wobec rzeczywistości politycznej doby Władysława Gomułki, [in:] Dzieje Kościoła katolickiego na Pomorzu Zachodnim, vol. 2: 1956-1972, eds. M. Siedziako, Z. Stanuch, G. Wejman, Szczecin 2018; idem, The idea of the common good and the reason of state in the teaching of primate Wyszyński, "Studia Theologica Varsaviensia" 2018, no. 2, pp. 65-82; idem, Czy Prymas Polski Stefan Wyszyński był antykomunista??, [in:] Antykomunizm Polaków w XX wieku, eds. P. Kardela, K. Sacewicz, Białystok-Olsztyn-Warszawa 2019, pp. 569-592; idem, Prymas Wyszyński wobec pozornej normalizacji relacji państwo-Kościół pierwszych lat rządów Edwarda Gierka (1971-1974), "Politeja” 2019, no. 60, pp. 349-371.

${ }^{42}$ R. Nęcek, Państwo w nauczaniu społecznym Prymasa Polski Stefana Wyszyńskiego, Kraków 2004.

${ }^{43}$ B. Noszczak, My Naród. Polska i Polacy w millenijnym programie prymasa Stefana Wyszyńskiego (1956-1966/1967), [in:] Prymas Wyszyński a Niepodległa. Naród - patriotyzm - państwo w myśli i nauczaniu Prymasa Tysiąclecia, eds. E. Czaczkowska, R. Łatka, Warszawa 2019; idem, Okoliczności uwolnienia kardynała Stefana Wyszyńskiego z internowania w Komańczy (październik 1956), "Studia Prymasowskie" 2007, vol. 1.

${ }^{44}$ K. Śmigiel, Prymasostwo polskie. Instytucja. Prymasi. Dokumenty, Warszawa 2018.

${ }^{45}$ W. J. Wysocki, Osaczanie prymasa. Kardynał Wyszyński jako "podopieczny" aparatu bezpieczeństwa w latach 1953-1956, Warszawa 2002.

${ }^{46}$ Z. Zieliński, Kościół w Polsce 1944-2002, Radom 2003; idem, Wielka Nowenna na tle powojennych losów Kościoła w Polsce, [in:] Ecclesia Posnaniensis. Opuscula Mariano Banaszak septuagenario dedicata, eds. F. Lenort, K. Lutyński, Poznań 1998; idem, Duszpasterski aspekt obchodów Tysiąclecia Chrztu Polski Kościół i prymas Stefan Wyszyński 1956-1966, eds. A. Dziurok, W. J. Wysocki, Katowice-Kraków 2008.

47 J. Żaryn, Dzieje Kościoła katolickiego w Polsce 1944-1989, Warszawa 2003; idem, Aresztowanie Prymasa Polski - okoliczności, przebieg, konsekwencje (1953-1956), "Studia Prymasowskie" 2007, vol. 1. 
The following publications should be considered as a particularly successful collective work on Cardinal Wyszyński: Kardynał Stefan Wyszyński. Prymas Tysiaclecia. Mąż Stanu. 1901-1981-2001 [Cardinal Stefan Wyszyński. Primate of the Millennium. Statesman. 1901-1981-2001], 2001; Kościót i prymas Stefan Wyszyński 1956-1966 [Church and Primate Stefan Wyszyński 1956-1966], 2008; [Primate Wyszyński and Catholic Culture], 2002; Prymas Wyszyński a niepodległa. Naród - patriotyzm - państwo w nauczaniu Prymasa Tysiaclecia [Primate Wyszyński and independent state. Nation - patriotism - state in the teaching of the Primate of the Millennium], 2019; Prymas Stefan Kardynat Wyszyński - świadek Ewangelii i tradycji narodowych. Materiaty sesji naukowej w Wyższym Seminarium Duchownym w Kielcach 19 maja 2001 r. [Primate Stefan Cardinal Wyszyński - a witness of the Gospel and national traditions. Materials from the scholarly session at the Higher Seminary in Kielce on 19 May 2001], 2001; Prymas Tysiaclecia w komunistycznym państwie [Primate of the Millennium in the Communist state], 2003; Stefan Wyszyński Prymas Tysiqclecia-absolwent KUL... kandydat na ottarze [Stefan Wyszyński Primate of the Millennium - a graduate of KUL... a candidate to altars], 2017; Stefan Wyszyński wobec opozycji i oporu społecznego 1945-1981 [Stefan Wyszyński against opposition and social resistance 1945-1981], 2018. It is also worth noting the publication "Studia Prymasowskie", which was published by UKSW between 2012 and 2017.

\section{Challenges with Source Materials}

The biographers of Cardinal Wyszyński are facing the massive task of accessing many archival sources. The Vatican Secret Archive and post-Soviet archives located in Russia, Ukraine, Lithuania, and Belarus are among the critical resources that have not yet been explored. Until now, these resources have not been appropriately analyzed to write Primate's biography ${ }^{48}$. Researchers, therefore, face the task of an in-depth query, publishing new source materials, and creatively circulating new information within the academic community. In the Vatican Secret Archive, Pius XII's legacy from the period of his pontifi-

48 The only exception is the source material: S. Wilk, A. D. Wójcik (eds.), Więzy jedności Jana XXIII i kardynała Stefana Wyszyńskiego, Lublin 2016. 
cate (1939-1958) has recently been available ${ }^{49}$. Without a doubt, the analysis of the Holy See's documentation from that period would make it possible to answer many questions such as the scope and nature of special powers granted to primates of Poland and, temporarily also to Cardinal Adam Stefan Sapieha ${ }^{50}$; the attitude of the Holy See to the activities of Cardinal Wyszyński in the years 1948-1958 with particular attention to the reaction to "Porozumienie" [Agreement] in April 195051; the Primate's approach to eastern politics of Vatican, which was known to be quite critical ${ }^{52}$; relations with Pius XII and subsequent popes.

The Archives of the Archdiocese of Gniezno is the most important for the reconstruction of the life and activity of Cardinal Wyszyński because the manuscript of his diary, Pro memoria, is kept there. Without its careful reading and analysis, it is impossible to write a complete biography of the Primate of the Millennium. So far, seven volumes of Pro memoria editions have been published, including scholarly annotations, covering the years from 1949 to $1961^{53}$. According to the project's coordinators' plans, the edition should be

49 Recently, G. Górny and J. Rosikon wrote an interesting take on the resources in this archive, Tajne Archiwum Watykańskie. Nieznane karty z historii Kościoła, [Vatican Secret Archive. Unknown records from the history of the Church], Warszawa 2020.

50 Z. Janczewski, Prerogatywy prymasów Polski, "Śląskie Studia Historyczno-Teologiczne” 1998, vol. 31, pp. 157-169; J. Krukowski, Uprawnienia nadzwyczajne kard. Stefana Wyszyńskiego, Prymasa Polski, wobec zagrożeń ze strony reżimu komunistycznego, "Studia Prymasowskie" 2001, vol. 5, pp. 29-42; J. Pietrzak, Petnia prymasostwa. Ostatnie lata prymasa Polski kardynała Augusta Hlonda 1945-1948, vol. 1, Poznań 2009, pp. 33-49; R. Łatka Episkopat Polski wobec rzeczywistości społeczno-politycznej PRL 1970-1989, Warszawa 2019, pp. 20-26; K. Śmigiel, P. Lewandowski (eds.), Uprawnienia wyjątkowe prymasa Stefana Wyszyńskiego. Wybór dokumentów 1948-1979, Pelplin 2020.

51 J. Żaryn, Kościół a władza w Polsce (1945-1950), Warszawa 1997.

52 R. Łatka, Episkopat Polski..., pp. 183-254 (a full list of references in this subject also there).

53 S. Wyszyński, Pro Memoria: Pro memoria vol. 1: 1948-1952, ed. P. Skibiński, Warszawa 2017; idem, Pro memoria vol. 2: 1953, ed. E. Czaczkowska, Warszawa 2017; idem, Pro memoria vol. 3: 1953-1956, eds. I. Czarcińska, A. Gałka, Warszawa 2018; Pro memoria vol. 5: 1953-1956, ed. M. Krupecka, Warszawa 2018; idem, Pro memoria vol. 7: 1960, ed. R. Łatka, Warszawa 2019; idem, Pro memoria vol. 8: 1961, ed. M. Wiśniewska, Warszawa 2019; idem, Pro memoria vol. 6: 1959, ed. G. Łeszczyński, Warszawa 2020. Excerpts from Pro memoria from the years 1965-1967 regarding millennium of baptism of Polish 
finished in about five years, so around 2025, the researchers will have a complete critical edition of the Cardinal's journal.

Accessing the collection of the Secretariat of the Primate of Poland located in the Archives of the Archdiocese in Warsaw is crucial to reconstruct the activities of Stefan Wyszyński during his service as a primate ${ }^{54}$. The essential documents in this resource include the minutes of plenary meetings of the Polish Episcopate and the Commission/Main Council's deliberations ${ }^{55}$. Other materials from this collection may also be useful, especially the correspondence of the Primate with the Holy See (and his correspondence with Pope Pius XII, John XXIII, Paul VI, John Paul I, and John Paul II), bishops, clergy, and laypeople. However, this requires an in-depth source examination.

Most certainly, a researcher aiming to write a biography of Cardinal Wyszyński should also reach to other church archives, focusing mainly on the sources of specific diocesan structures such as Archdiocese of Kraków, Archdiocese of Poznań, Archdiocese of Wrocław, Diocese of Lublin, Diocese of Łódź, Diocese of Przemyśl, which were the most important places during the activity of Cardinal Wyszyński. It would also be necessary to review again, with the biographical purpose in mind, the resources of the Diocesan Archives in Włocławek and the Archdiocesan Archive in Lublin, in order to verify whether the previous researchers used all of the most important sources concerning the life and activities of Stefan Wyszyński in the years 1920-1946 (although it seems that possible source findings will only be of minor importance).

The critical task for biographers of Cardinal Wyszyński is to examine extensive and diverse resources of public appearances the Cardinal, gathered in the AIPSKW archives in Choszczówka. To date, nineteen volumes of Dzieła zebrane [Collected works] by Stefan Wyszyński have been published containing authorized homilies and speeches delivered by the Primate ${ }^{56}$. In addition to these, one should review the subsequent fifty volumes put in order by the

state are also available in a separate publication. S. Wyszyński, Zapiski millenijne. Wybór $z$ dziennika "Pro memoria" z lat 1965-1967, Warszawa 2001.

54 W. R. Mocko, Sekretariat Prymasa Polski. 25 lat posługi prymasowskiej Józefa Kardynała Glempa, Warszawa, n.d.

55 The importance of these materials for the study of the history of the Catholic Church in the Polish People's Republic and the role of Primate Wyszynski was described in R. Łatka, Episcopate Polski..., p. 12.

56 S. Wyszyński, Dzieła zebrane, vol. I-XIX, Warszawa 1991-2018. 
archive employees and review unauthorized speeches. It is a huge undertaking, as the complete resource includes between twelve and thirteen thousand speeches. An additional and valuable resource of this institution is iconographic material, including more than twenty thousand Primate Wyszyński photos from public celebrations and private events (numerous photos from his holidays). Part of those speeches of Cardinal Wyszyński was, of course, already published in various collections, usually arranged by topic ${ }^{57}$.

Due to the position and importance of the Primate as a person and the range of his activities, an in-depth query in the state archives is also necessary. The Archives of New Records (AAN) and the Archives of the Institute of National Remembrance in Warsaw (AIPN) are most relevant. In the first one, one can find the documentation of the PZPR (Polish United Workers' Party) and political structures that the Office for Religious Denominations, which, on behalf of the state, was responsible for any official dealings with the Church. In the documentation of these units, one can find various materials concerning Cardinal Wyszyński, especially the social activity of the Church and the authorities' policies toward the same. The other archive (AIPN) materials with surveillance and materials used to work out all church structures, including the Primate. Important elements are transcripts of sermons and speeches of Cardinal Wyszyński prepared by the security apparatus, tracking his pastoral and political activities. Two source editions from the collection of IPN containing documentation on Cardinal Wyszyński are useful for researchers: Stefan Kardynał Wyszyński Prymas Polski w dokumentach aparatu bezpieczeństwa PRL (1953-1956) [Stefan Cardinal Wyszyński, Primate of Poland in the documents of the security apparatus of the PRL (1953-1956)], 2001; W stużbie Boga i Polski. Komunistyczna bezpieka wobec Kardynała Stefana Wyszyńskiego [In the service of God and Poland. Communist security service against Cardinal Stefan Wyszyński], 2014.

Additionally, an analysis of documents from the various state archives (provincial) and branch archives of the IPN (eleven divisions and five local agencies) should also be considered. Of course, reviewing the materials from all the collections mentioned above exceeds the capabilities of not just one but even a team of researchers. For this reason, it must be a targeted query

57 S. Wyszyński, Z rozważań nad kulturą ojczystą, Poznań-Warszawa 1979; idem, Nauczanie społeczne 1946-1981, Warszawa 1990; idem, Na szlaku tysiq̨clecia. Wybór kazań, eds. M. Okońska, M. Plaskacz, A. Rastawicka, Warszawa 1996. 
focused on issues relevant to the life and activities of Cardinal Wyszynski. Publications with opinions of the Primate on different parts of Poland can be helpful here too ${ }^{58}$. However, there is no comprehensive publication about Cardinal Wyszyński's opinions and position toward the most important places in his life - Warszawa, Gniezno, Jasna Góra, Włocławek, and Lublin.

When preparing a biography of Cardinal Wyszyński, one should access pastoral letters of the Primate of Poland ${ }^{59}$, and the Polish Episcopate ${ }^{60}$, the source edition concerning state-church relations in the Polish People's Republic ${ }^{61}$, and also, memoirs and accounts of the Primate's associates with a particular focus on Romuald Kukołowicz, and Fr. Bronisław Piasecki ${ }^{62}$.

${ }^{58}$ The publications by A. Dziurok, J. Myszor, Prymas Stefan Wyszyński a Górny Śląsk - kontekst, wizyty, wystapienia, Katowice 2020, should be considered as exemplary. The authors thoroughly analyzed all connection of Card. Wyszyński with Upper Silesia, introduced his relations with the bishops of Katowice and the clergy; they also described his visits to this region. Another valuable publication is by S. Wyszyński, Jasnogórskie wspomnienia. Zapiski osobiste, Częstochowa 2018. As for other parts of Poland, it is worth noting following publications: T. Dzwonkowski, Cz. Osękowski (eds.), Stefan Kardynał Wyszyński wobec Ziem Zachodnich i Pótnocnych oraz stosunków polsko-niemieckich. W 100-lecie urodzin Prymasa Tysiqclecia, Warszawa-Poznan-Zielona Góra 2001; W. Kucharski, Ziemie Zachodnie i Pótnocne jako racja stanu w myśli i działaniach prymasa Stefana Wyszyńskiego w latach 1948-1972 (ze szczególnym uwzględnieniem archidiecezji wrocławskiej, [w:] Prymas Wyszyński a Niepodległa..., pp. 227-249; D. Zamiatała, Prymas Wyszyński wobec Ziem Zachodnich, [w:] ibidem, pp. 251-271; W. Konopka, Pobyty prymasa Stefana Wyszyńskiego w Toruniu. Z dziejów Kościoła katolickiego w Polsce po II wojnie światowe, Toruń 2012.

${ }^{59}$ Listy pasterskie Prymasa Polski 1946-1974, Paris 1975.

${ }^{60}$ Listy pasterskie Episkopatu Polski 1945-1974, Paris 1975; J. Żaryn (ed.), Komunikaty Konferencji Episkopatu Polski 1945-2000, Poznań 2006.

${ }^{61}$ The two most important series from the central point of view during the primacy of Stefan Wyszyński are by P. Raina, Kościót w PRL. Kościót katolicki a państwo w świetle dokumentów 1945-1989, vol. 1-3, Poznań-Pelplin 1995-1996; Tajne dokumenty państwoKościót 1960-1980, London 1996.

${ }^{62}$ M. Plaskacz, A. Rastawicka, W. Wojdecki, Człowiek niezwykłej miary. Ojciec Święty Jan Paweł II o kardynale Stefanie Wyszyńskim. Kardynat Stefan Wyszyński o sobie. Kardynat Józef Glemp o kardynale Stefanie Wyszyńskim, Warszawa 1984; R. Kukołowicz, W cieniu Prymasa Tysiqclecia. Z Romualdem Kukołowiczem rozmawia Piotr Bączek, Warszawa 2001; B. Piasecki, Ostatnie dni Prymasa Tysiąclecia, Poznań 2001; B. Piasecki, M. Zając, Prymas Wyszyński. Ojciec duchowy widziany z bliska, Kraków 2016. 


\section{The Challenges of Interpretation Related to the Primate Period}

Biographers of Cardinal Wyszyński face a severe challenge of embracing vast amounts of source material and literature on the subject and problems with interpretation related to the Primate of the Millennium's life and activities. Below, I outline the most important and, in my opinion, most interesting ones. Of course, the following list is not complete, and one can certainly describe other points from Cardinal's rich biography, which are also worth raising.

A research problem relating to the description of activities of Stefan Wyszyński in his long life, which continued over four historical periods - partitioned Poland and World War I (1901-1918), the Second Polish Republic (1918-1939); World War II (1939-1945) and finally, the most extended and most important period of People's Poland (1945-1981). Each of these periods has a specific context that must be presented more closely to fully understand the historical role of the Primate and the influence of his earlier experiences on his ministry.

Another key point in interpreting Primate's biography is that he was first and foremost a priest and a bishop, not a politician or statesman (whom he became out of necessity), and was primarily guided by the gospel in his life and activities. Taking such a perspective in a biography of Cardinal Wyszyński is essential to avoid misinterpretations of the Primate's activities countered with political calculations at the time. A good illustration may be the Primate's stance in the message of Polish bishops to German bishops, when the gospel message of forgiveness prevailed over possible problems that could have been caused in the relations between the Church and the communist state and, subsequently could have resulted in a critical reaction of society ${ }^{63}$.

63 Cardinal Wyszyński was fully aware that from a political point of view this was a risky step. The Primate interestingly summed up the effects of the authorities' propaganda rebuking the message delivered on January 13, 1966: "This message caused perhaps some confusion here in this country, especially among intelligence, but out in the world it further raised the position of the Polish Church, improved the opinions about this Church and made all allegations of chauvinism, nationalism disappear immediately". (P. Madajczyk, Na drodze pojednania. Wokół orędzia biskupów polskich do biskupów niemieckich z 1965 r., Warszawa 1994, p. 226). 
Further research challenges can be divided into two main categories Wyszyński's role as a leader of the Church in Poland and, more broadly, the universal Church and his activity in the non-religious sphere as a statesman.

In the first category, one should note an aspect poorly recognized thus far, that is, activities of the Cardinal in service to the universal Church. There is no publication on this subject, and the monographic sources listed earlier in this paper did not give too much attention to this matter ${ }^{64}$. Much attention should also be given to the Primate's relationship with the successive popes - Pius XII, John XXIII, Paul VI, John Paul I and John Paul II, and various Holy See institutions. Until now, this topic has been described in many publications, but first of all, their authors did not have access to Vatican documentation and presented this issue mainly from the Polish (rather than European or world) perspective.

Another important issue is the comprehensive description of the leadership model of Cardinal Wyszyński in the Polish Church and the scope of special powers (which certainly facilitated the activities of the Primate and gave him the tools to be a leader). Most researchers followed the paper trail of the party and the state documentation and materials of security services which indicated that the Primate was acting like a dictator and an autocrat in the Polish Episcopate. However, Paweł Skibiński aptly noted that "judging both by reading the minutes and reading transcripts of selected audio files at the plenary conferences of the Episcopate and, above all, on the lower governing body of the local Polish Church (the General Council of the Polish Episcopate,) the discussions at the time we substantive and full of merit. During those, bishops did not seem to be constrained by the Primate's authority. Very often, Wyszyński, realizing his great authority, only summed up discussions on sensitive issues and did not want to suggest ready-made solutions to the bishops. It also needs pointing out that, especially at the General Council, the Primate not always of course, but sometimes was convinced by the bishops in a discussion"65. I was so far the only researcher who has sought to give this matter more attention by presenting Cardinal Wyszyński as a charismatic leader

64 Skibiński was the first to come to the attention of this. See: idem, Stefan kardynat Wyszyński - znaczenie dla Kościoła powszechnego, "Biuletyn IPN” 2020 no. 6, p. 15-24.

65 P. Skibiński, Biskupi polscy w okresie PRL - głos w dyskusji panelowej [in:] Biskupi w rzeczywistości politycznej Polski "ludowej”, ed. Łatka, R., Warszawa 2020, p. 46. 
and the one who noticed other Polish bishops' talents and made use of it ${ }^{66}$. In general, Wyszyński's relations with the Church hierarchy in Poland require a more profound study. At the moment, we have only some studies on his relationship with Archbishop Antoni Baraniak ${ }^{67}$, Bp. Zygmunt Choromański68, Bp. Bronisław Dąbrowski ${ }^{69}$, Bp. Michał Klepacz ${ }^{70}$, Card. Bolesław Kominek ${ }^{71}$, and Card. Karol Wojtyła ${ }^{72}$. One should note that the publications on this subject are primarily causative in their character. The Cardinal's relationship with superiors of religious orders (both in Poland and within central structures of religious orders) also calls for a deeper analysis. The only researcher studying this issue more broadly is Fr. Dominik Zamiatała ${ }^{73}$.

At present, we also do not have any severe works devoted to Cardinal Wyszyński as a metropolitan of Gniezno and Warsaw. This research gap must be filled, as it will be challenging to write a complete biography without studying his ministry as a diocesan bishop. A monographic publication or detailed work on this topic will also help show how the Primate arranged his relationships with the clergy, both the closest co-workers of the Curia and the lower clergy. Reading Pro memoria leads to cautious conclusions that the Primate was a demanding but just superior. An interesting issue is the model of functioning of the Archdiocese of Gniezno where, as we know from Pro memoria, Cardinal Wyszyński stayed for a week each month and during the remaining

66 R. Łatka, Episkopat Polski..., p. 19 in: idem, Prymas Stefan Wyszyński. Niekwestionowany przywódca, Biuletyn IPN” 2020 no. 6, pp. 50-59

67 R. Łatka, Arcybiskup Antoni Baraniak najważniejszy wspótpracownik Prymasa Stefana Wyszyńskiego, Myśl.pl, 2018 no. 1, pp. 93-95; idem, Arcybiskup Antoni Baraniak jako członek Episkopatu Polski cz. I (1951-1967), "Seminare” 2019 no. 3, pp. 185-200; idem, Arcybiskup Antoni Baraniak jako członek Episkopatu Polski cz. II (1967-1977), "Seminare" 2020 no. 1, pp. 129-140.

68 M. G. Smoliński, Biskup negocjator. Zygmunt Choromański 1892-1968. Biografia niepolityczna?, Warszawa 2014.

69 P. Raina, Arcybiskup Bronisław Dabrowski. Portret, Warszawa 2008.

70 E. Ślązak, Prymas i biskup. Relacje kard. Stefana Wyszyńskiego z bp. Michałem Klepaczem, "Biuletyn IPN” 2020, no. 6, pp. 42-49.

71 K. Jaworska, Kardynał Stefan Wyszyński i kardynał Bolesław Kominek - wzajemne relacje" "Seminars" 2018, no. 2, pp. 175-188.

${ }^{72}$ Niezłomni. Wspólne dzieje kardynała Karola Wojtyły i Prymasa Tysiąclecia, Kraków 2009.

73 D. Zamiatała, Zakony męskie a episkopat w latach 1945-1989, Lublin 2009. 
time, the auxiliary bishops managed the Archdiocese. Undoubtedly, this was an unusual arrangement developed for the time that was not typical either. The analysis of Wyszyński's role as an ordinary should be complemented by looking into his role as the guardian of church structures in the western and northern regions he held (because of special powers) between 1948 and 1972 . Cardinal Wyszyński also influenced the functioning of the Church in these areas in the following years. The battle he had to fight with authorities of the Polish People's Republic to be appointed the Metropolitan of Wrocław after the death of Cardinal Kominek in 1974 can attest to the same ${ }^{74}$.

Researchers also face a challenge to shed more light on the circles of most important co-workers of Cardinal Wyszyński, both in the central management of the Church in Poland and the two provinces in which he was an ordinary. The second important aspect crucial for understanding Cardinal Wyszyński is finding a suitable interpretive key to describe his public activity going beyond strictly confessional terms. When analyzing this issue, several key points need to be highlighted below.

First and foremost, the social activities of the Primate stemmed directly from church functions he performed and fulfilling at the same time a pastoral mission of the Church - this social activity was always secondary both in Wyszyński's teaching and his actions. Researchers face the task of analyzing the entire intellectual legacy of Cardinal Wyszyński and answering the question about the most important social interests of the Primate and how they influenced his teaching and daily activities. Some theological and sociological studies on this subject will be helpful and an insight into different aspects of Cardinal's homiletic message.

Secondly, it is necessary to point to the extreme patriotism of Cardinal Wyszyński, who had always emphasized that he loved his homeland and that he was ready for the highest sacrifice for her ${ }^{75}$. The Primate reflects this in his statement from the turn of 1956 and 1957, saying, "if I knew that to save the nation I had to go on my knees to the KC [Central Committee], I would do it.

${ }^{74}$ P. Raina, Sprawa obsadzenia metropolii wrocławskiej. Eskapady władz PRL 1974-1976, Pelplin 2003; R. Eatka, Episkopat Polski..., p. 25 in: idem, Rozmowy operacyjne funkcjonariuszy SB z kardynałem Henrykiem Gulbinowiczem (1969-1985), "Glaukopis" 2020, no. 37, pp. 167-177.

75 Prymas Stefan Wyszyński a Niepodległa... 
I myself am not important, but the existence and survival of the people is"76. It would therefore be necessary to describe in any future biography how the Primate's patriotism influenced his activities in the non-confessional sphere.

Thirdly, Cardinal Wyszyński had an analytical sense of socio-political reality and was a very well-informed person (perhaps even the best informed of all Polish People's Republic) citizens. Indeed, potential biographers face the demanding challenge of reconstructing the circle of people who were providing information to him (including those from party circles). Also, Primate's approach to state-church relations in a communist-dominated state must be described comprehensively. This aspect is perhaps most evident in the historical studies on Cardinal Wyszyński, but an in-depth reflection on this issue is still lacking ${ }^{77}$. Another matter is Cardinal Wyszyński's relation with the consecutive first secretaries of the KC PZPR, with whom he met during his long service. These were - Bolesław Bierut, Władysław Gomułka, Edward Gierek, Stanisław Kania, and Wojciech Jaruzelski (Jaruzelski was the prime minister of the Polish People's Republic at the time he met with the Primate).

\section{SUMMARY}

As these considerations point out, biographers of Cardinal Wyszyński most certainly face various challenges. The main ones are gathering and reviewing many archival sources from the Church collection and state archives. There are also several problems with the interpretation of these findings. Although no guarantee overcoming those research problems would result in a comprehensive scholarly biography of the Primate of the Millennium, this seems the only way to achieve this. The studies currently available in the publishing market do not fulfill the task.

${ }^{76}$ R. Łatka, Prymas Wyszyński wobec rzeczywistości..., p. 51.

${ }^{77}$ It seems that I managed to describe this issue for the last decade of the life of Cardinal Wyszyński in detail in: R. Łatka, Episkopat Polski... 


\section{BIBLIOGRAPHY}

\section{REFERENCES}

\section{Published documents}

Leszczyński M. (ed.), Protokoły wizytacji kanonicznych przeprowadzonych przez biskupa lubelskiego Stefana Wyszyńskiego w parafiach na terenie obecnej diecezji zamojsko-lubaczowskiej 1946-1948, Warszawa 2020.

Listy pasterskie Episkopatu Polski 1945-1974, Paris 1975.

Listy pasterskie Prymasa Polski 1946-1974, Paris 1975.

Marecki J., Nitecki P., Szczypta-Szczęch R. (eds.), W służbie Boga i Polski. Komunistyczna bezpieka wobec Kardynała Stefana Wyszyńskiego, Kraków 2014.

Raina P., Kościół w PRL. Kościót katolicki a państwo w świetle dokumentów 1945-1989, vol. 1-3, Poznań-Pelplin 1995-1996.

Romaniuk M. P., Prymas Tysiąclecia w słowie pisanym. Bibliografia życia, twórczości i posługi Kardynała Stefana Wyszyńskiego 1921-2017, vol.1-2, Warszawa 2018.

Stefan Kardynał Wyszyński Prymas Polski $w$ dokumentach aparatu bezpieczeństwa PRL (1953-1956), ed. B. Piec, Warszawa 2001.

Śmigiel K., Lewandowski P, (ed.), Uprawnienia wyjątkowe prymasa Stefana Wyszyńskiego. Wybór dokumentów 1948-1979, Pelplin 2020.

Tajne dokumenty państwo-Kościót 1960-1980, London 1996.

Wilk, S., Wójcik, A. D. (ed.), Więzy jedności Jana XXIII i kardynała Stefana Wyszyńskiego, Lublin 2016.

Wyszyński S., Dzieła zebrane, v. I- XIX, Warszawa 1991-2018.

Wyszyński S., Jasnogórskie wspomnienia. Zapiski osobiste, Częstochowa 2018.

Wyszyński S., Katolicka nauka społeczna. Wybór artykułów z "Ateneum Kapłańskiego" z lat 1929-1946, Włocławek 2001.

Wyszyński S., Na szlaku tysiąclecia. Wybór kazań, eds. M. Okońska, M. Plaskacz, A. Rastawicka, Warszawa 1996.

Wyszyński S., Nauczanie społeczne 1946-1981, Warszawa 1990.

Wyszyński S., Początki nauczania społecznego (1934-1939), Warszawa 2001.

Wyszyński S., Pro Memoria, vol. I: 1948-1952, ed. P. Skibiński, Warszawa 2017.

Wyszyński S., Pro Memoria, vol. II: 1953, ed. E. Czaczkowska, Warszawa 2017.

Wyszyński S., Pro Memoria, vol. III: 1953-1956, eds. I. Czarcińska, A. Gałka, Warszawa 2018.

Wyszyński S., Pro Memoria, vol. V: 1958, ed. M. Krupecka, Warszawa 2018.

Wyszyński S., Pro memoria, vol. 6: 1959, ed. G. Łeszczyński, Warszawa 2020.

Wyszyński S., Pro memoria, vol. 7: 1960, ed. R. Łatka, Warszawa 2019.

Wyszyński S., Pro memoria, vol. 8: 1961, ed. M. Wiśniewska, Warszawa 2019.

Wyszyński S., Zapiski millenijne. Wybór z dziennika "Pro Memoria" z lat 1965-1967, eds. M. Okońska, M. Plaskacz, A. Rastawicka, Warszawa 2001.

Wyszyński S., Z rozważań nad kulturą ojczystą, Poznań-Warszawa 1979. 


\section{R. EATKa $\|$ Challenges of A Scholarly Biography of Primate...}

Żaryn J. (ed.), Komunikaty Konferencji Episkopatu Polski 1945-2000, Poznań 2006.

\section{Memoirs and narratives}

Kukołowicz R., W cieniu Prymasa Tysiąclecia. Z Romualdem Kukołowiczem rozmawia Piotr Bączek, Warszawa 2001.

Piasecki B., Ostatnie dni Prymasa Tysiąclecia, Poznań 2001.

Piasecki B., Zając M., Prymas Wyszyński. Ojciec duchowy widziany z bliska, Kraków 2016.

Plaskacz M., Rastawicka A., Wojdecki W. (eds.), Człowiekniezwykłej miary. Ojciec Święty Jan Paweł II o kardynale Stefanie Wyszyńskim. Kardynał Stefan Wyszyński o sobie. Kardynał Józef Glemp o kardynale Stefanie Wyszyńskim, Warszawa 1984.

\section{STUDIES}

Bagrowicz J., "Najmilszy trud mego życia”. Ksiądz Stefan Wyszyński jako redaktor i publicysta, "Ateneum Kapłańskie" 2001, vol. 553, no. 3.

Bartnik Cz. S., Chrześcijańska nauka o narodzie według prymasa Wyszyńskiego, Rzym 1982.

Czaczkowska E., Kardynał Wyszyński. Biografia, Kraków 2013.

Czaczkowska E., Prymas Polski Stefan kardynał Wyszyński na Soborze Watykańskim II, [in:] Studia Soborowe vol. 1: Historia i nauczanie Vaticanum II, ed. M. Białkowski, Toruń 2013.

Czaczkowska E. (ed.), Prymas Wyszyński wobec opozycji i oporu społecznego 1945-1981, Warszawa 2018.

Czaczkowska E., Prymas Wyszyński. Wiara, nadzieja, miłość, Kraków 2020.

Czaczkowska E., Łatka R. (eds.), Prymas Stefan Wyszyński a Niepodległa. Naród - patriotyzm - państwo w myśli i nauczaniu Prymasa Tysiaclecia, Warszawa 2019.

Czarnowski R., U kolebki życia Prymasa Tysiąclecia. W setnq rocznicę urodzin i chrztu Stugi Bożego Kardynała Stefana Wyszyńskiego, Łomża 2001.

Droga życia. Stefan Kardynał Wyszyński, Bydgoszcz 2001.

Dybciak K. (ed.), Prymas Wyszyński a kultura katolicka, Warszawa 2002.

Dziurok A., Prymas Stefan Wyszyński wobec władz komunistycznych w latach 1949-1956, "Studia Prymasowskie" 2012, vol. 6.

Dziurok A., Myszor J., Prymas Stefan Wyszyński a Górny Śląsk - kontekst, wizyty, wystapienia, Katowice 2020.

Dziurok A., Wysocki W. J. (eds.), Kościół i prymas Stefan Wyszyński 1956-1966, Katowice-Kraków 2008.

Dzwonkowski T., Osękowski Cz. (eds.), Stefan Kardynał Wyszyński wobec Ziem Zachodnich i Północnych oraz stosunków polsko-niemieckich. W 100-lecie urodzin Prymasa Tysiąclecia, Warszawa-Poznań-Zielona Góra 2001.

Eisler J., Stefan Wyszyński i Władysław Gomułka - dwie wizje Polski, [in:] Pojednanie i polityka. Polsko-niemieckie inicjatywy pojednania w latach sześćdziesiątych XX wieku a polityka odprężenia, eds. F. Boll, W. J. Wysocki, K. Zimmer, Warszawa 2010. 
Friszke A., Tajemnice Andrzeja Micewskiego, “Tygodnik Powszechny”, 21 August 2006. Górny G., Rosikoń J., Tajne Archiwum Watykańskie. Nieznane karty z historii Kościoła, Warszawa 2020.

Grajewski A., Jesień Prymasów. Kardynałowie Mindszenty i Wyszyński wobec przełomu 1956 roku, "Studia Prymasowskie" 2012, vol. 6.

Grajewski A., Kardynatowie Stefan Wyszyński i Agostino Casaroli - dwie osobowości i dwie koncepcje polityki wschodniej Watykanu, "Studia Prymasowskie" 2009, vol. 3.

Janczewski Z., Prerogatywy Prymasów Polski, "Śląskie Studia Historyczno-Teologiczne" 1998, vol. 31.

Jaworska K., Kardynał Stefan Wyszyński i kardynat Bolesław Kominek - wzajemne relacje, "Seminare" 2018 no. 2.

Jerzmański H. (ed.), Kardynał Stefan Wyszyński. Prymas Tysiąclecia. Mąż Stanu. 1901-1981-2001, Warszawa 2001.

Konopka W., Pobyty prymasa Stefana Wyszyńskiego w Toruniu. Z dziejów Kościoła katolickiego w Polsce po II wojnie światowej, Torun 2012.

Krukowski J., Uprawnienia nadzwyczajne kard. Stefana Wyszyńskiego, Prymasa Polski, wobec zagrożeń ze strony reżimu komunistycznego, "Studia Prymasowskie" 2001, vol. 5.

Kucharski W., Ziemie Zachodnie i Pótnocne jako racja stanu w myśli i działaniach prymasa Stefana Wyszyńskiego w latach 1948-1972 (ze szczególnym uwzględnieniem archidiecezji wrocławskiej, [in:] Prymas Wyszyński a Niepodległa. Naród - patriotyzm państwo w myśli i nauczaniu Prymasa Tysiąclecia, eds. E. Czaczkowska, R. Łatka, Warszawa 2019.

Kujawski W., Szkic włocławskich dziejów Stefana Wyszyńskiego, "Ateneum Kapłańskie" 2001, no. 553, issue 3.

Laskowska M., Praca dziennikarska i redaktorska ks. Stefana Wyszyńskiego w latach 1924-1946, "Studia Prymasowskie" 2009, vol. 3.

Lewandowski J., Naród w nauczaniu kardynała Stefana Wyszyńskiego, Warszawa 1989. Łatka R., Arcybiskup Antoni Baraniak jako członek Episkopatu Polski cz. I (1951-1967), "Seminare" 2019, no. 3.

Łatka R., Arcybiskup Antoni Baraniak jako członek Episkopatu Polski cz. II (1967-1977), "Seminare" 2020, no. 1.

Łatka R., Arcybiskup Antoni Baraniak najważniejszy wspótpracownik Prymasa Stefana Wyszyńskiego, Myśl.pl, 2018, no. 1.

Łatka R., "Bronić Solidarność przed wkraczaniem na tereny polityczne". Prymas Stefan Wyszyński wobec Solidarności, [in:] Stefan Wyszyński wobec opozycji i oporu społecznego 1945-1981, ed. E. Czaczkowska, Warszawa 2018.

Łatka R., Czy Prymas Polski Stefan Wyszyński był antykomunistą?, [in:] Antykomunizm Polaków w XX wieku, eds. P. Kardela, K. Sacewicz, Białystok-Olsztyn-Warszawa 2019.

Łatka R., Czy prymasa Wyszyńskiego można określać mianem realisty politycznego?, [in:] Realizm polityczny, ed. R. Łatka, "Politeja" 2013, no. 25. 


\section{R. EATKa $\|$ Challenges of A Scholarly Biography of Primate...}

Łatka R., Episkopat Polski wobec rzeczywistości społeczno-politycznej PRL 1970-1989, Warszawa 2019.

Łatka R., Koniec odwilży w relacjach państwo-Kościół (1957-1958) z perspektywy prymasa Stefana Wyszyńskiego, [in:] Księga pamiątkowa dla bp. Edwarda Frankowskiego, eds. M. Krzysztofiński, J. Wołczański, Rzeszów 2018.

Łatka R., "Normalizacja" relacji państwo-Kościół w latach siedemdziesiątych XX wieku z perspektywy Prymasa Stefana Wyszyńskiego - nieznany dokument z Sekretariatu Prymasa Polski, "Pamięć i Sprawiedliwość" 2018, no. 2.

Łatka R., Problemy metodologiczne w prowadzeniu badań na temat historii Kościoła katolickiego w Polsce "ludowej". Przegląd badań, postulaty badawcze, "Dzieje Najnowsze" 2016, no. 1.

Łatka R., Prymas Stefan Wyszyński wobec zagrożenia interwencją sowiecka 1980-1981, "Studia z dziejów Rosji i Europy Środkowo-Wschodniej” 2017, vol. 1.

Łatka R., Prymas Stefan Wyszyński. Niekwestionowany przywódca, "Biuletyn IPN" 2020, no. 6.

Łatka R., Prymas Wyszyński wobec pozornej normalizacji relacji państwo - Kościół pierwszych lat rządów Edwarda Gierka (1971-1974), "Politeja” 2019, no. 60.

Łatka R., Prymas Wyszyński wobec rzeczywistości politycznej doby Władysława Gomułki, [in:] Dzieje Kościoła katolickiego na Pomorzu Zachodnim, vol. 2: 1956-1972, eds. M. Siedziako, Z. Stanuch, G. Wejman, Szczecin 2018.

Łatka R., Rozmowy operacyjne funkcjonariuszy SB z kardynałem Henrykiem Gulbinowiczem (1969-1985), "Glaukopis” 2020, no. 37.

Eatka R., The idea of the common good and the reason of state in the teaching of primate Wyszyński, "Studia Theologica Varsaviensia" 2018, no. 2.

Łatka R., Mackiewicz B., Zamiatała D., Prymas Stefan Wyszyński. Biografia, Warszawa 2020.

Łęcicki G., Harcerz, ułan, kapłan. Ks. Zdzisław Peszkowski, Warszawa 2012.

Madajczyk P., Na drodze pojednania. Wokół orędzia biskupów polskich do biskupów niemieckich z 1965 r., Warszawa 1994.

Mażewski L., Prymas Stefan Kardynał Wyszyński wobec Polski po 1944/1945 r. Elementy analizy ustrojoznawczej i geopolitycznej, Warszawa 2020.

Micewski A., Kardynał Wyszyński, Prymas i mąż stanu, Paris 1982.

Micewski A., Stefan Kardynał Wyszyński (1901-1981), Warszawa 2000.

Micewski A., Wspótrządzić czy nie kłamać, PAX i Znak w Polsce 1945-1976, Paris 1978.

Mocko W. R., Sekretariat Prymasa Polski. 25 lat posługi prymasowskiej Józefa Kardynała Glempa, Warszawa, n.d.

Nęcek R., Państwo w nauczaniu społecznym Prymasa Polski Stefana Wyszyńskiego, Kraków 2004.

Niezłomni. Wspólne dzieje kardynała Karola Wojtyły i Prymasa Tysiąclecia, Kraków 2009.

Nitecki P., Ksiądz Stefan Wyszyński jako profesor katolickiej nauki społecznej we Włocławku (1931-1939), "Studia Prymasowskie" 2007, vol. 1.

Nitecki P., Ksiądz Stefan Wyszyński w perspektywie rozpoznania komunizmu, "Studia Prymasowskie" 2009, vol. 3. 
Nitecki P., Wiem jak godnq stolicę obejmuję w dziedzictwie”. Biskup Stefan Wyszyński pasterz Kościoła lubelskiego, Lublin 2012.

Nitecki P., Włocławskie dzieje ks. Stefana Wyszyńskiego 1917-1946, Wrocław 2008.

Noszczak B., My Naród. Polska i Polacy w millenijnym programie prymasa Stefana Wyszyńskiego (1956-1966/1967), [in:] Prymas Wyszyński a Niepodległa. Naród - patriotyzm - państwo w myśli i nauczaniu Prymasa Tysiq̨clecia, eds. E. Czaczkowska, R. Łatka, Warszawa 2019.

Noszczak B., Okoliczności uwolnienia kardynała Stefana Wyszyńskiego z internowania w Komańczy (październik 1956), "Studia Prymasowskie" 2007, vol. 1.

Pietrzak J., Petnia prymasostwa. Ostatnie lata prymasa Polski kardynała Augusta Hlonda 1945-1948, vol. 1-2, Poznań 2009.

Prymas Stefan Kardynał Wyszyński - świadek Ewangelii i tradycji narodowych. Materiały sesji naukowej w Wyższym Seminarium Duchownym w Kielcach 19 maja 2001 r., Kielce 2001.

Pylak B., Stefan Wyszyński Biskup Lubelski, Lublin 2000.

Raina P., Arcybiskup Bronisław Dąbrowski. Portret, Warszawa 2008.

Raina P., Sprawa obsadzenia metropolii wrocławskiej. Eskapady władz PRL 1974-1976, Pelplin 2003.

Raina P., Stefan kardynał Wyszyński prymas Polski, vol. 1-3, London 1979-1988.

Raina, Stefan Kardynał Wyszyński. Prymas Tysiąclecia, vol. 1-5, Warszawa 2016.

Romaniuk M. P., Życie, twórczość i posługa Stefana Kardynała Wyszyńskiego Prymasa Tysiąclecia, vol. 1-4, Warszawa 1994-2002.

Sitarz M., Słowikowska A., Romanko A. (eds.), Stefan Wyszyński, Prymas Tysiacleciaabsolwent KUL... kandydat na ołtarze, Lublin 2017.

Skibiński P., Biskupi polscy w okresie PRL - głos w dyskusji panelowej, [in:] Biskupi w rzeczywistości politycznej Polski “ludowej”, ed. R. Łatka, Warszawa 2020.

Skibiński P., Do jakiego stopnia PRL był państwem polskim? Ocena prymasa Wyszyńskiego, [in:] Prymas Stefan Wyszyński a Niepodległa. Naród - patriotyzm - państwo w myśli i nauczaniu Prymasa Tysiąclecia, eds. E. Czaczkowska, R. Łatka, Warszawa 2019.

Skibiński P., Stefan kardynał Wyszyński- znaczenie dla Kościoła powszechnego, "Biuletyn IPN" 2020, no. 6.

Smoliński M. G., Biskup negocjator. Zygmunt Choromański 1892-1968. Biografia niepolityczna?, Warszawa 2014.

Stefan Kardynał Wyszyński. Biografia w fotografiach, Orchard Lake 1969.

Ślązak E., Prymas i biskup. Relacje kard. Stefana Wyszyńskiego z bp. Michałem Klepaczem, "Biuletyn IPN" 2020, no. 6.

Śmigiel K., Prymasostwo polskie. Instytucja. Prymasi. Dokumenty, Warszawa 2018.

Wysocki W. J., Osaczanie prymasa. Kardynał Wyszyński jako "podopieczny" aparatu bezpieczeństwa w latach 1953-1956, Warszawa 2002.

Zabłocki J., Prymas Stefan Wyszyński. Opór i zwycięstwo 1948-1956, Warszawa 2002. 
Zamiatała D., Prymas Wyszyński wobec Ziem Zachodnich, [in:] Prymas Wyszyński a niepodległa. Naród - patriotyzm - państwo w nauczaniu Prymasa Tysiąclecia, eds. E. K. Czaczkowska, R. Łatka, Warszawa 2019.

Zamiatała D., Zakony męskie a episkopat w latach 1945-1989, Lublin 2009.

Zieliński Z., Duszpasterski aspekt obchodów Tysiąclecia Chrztu Polski Kościót i prymas Stefan Wyszyński 1956-1966, eds. A. Dziurok, W. J. Wysocki, Katowice-Kraków 2008.

Zieliński Z., Kościót w Polsce 1944-2002, Radom 2003.

Zieliński Z. (ed.), Prymas Tysiąclecia w komunistycznym państwie, Radom 2003.

Zieliński Z., Wielka Nowenna na tle powojennych losów Kościoła w Polsce, [in:] Ecclesia Posnaniensis. Opuscula Mariano Banaszak septuagenario dedicata, eds. F. Lenort, K. Lutyński, Poznań 1998.

Żaryn J., Aresztowanie Prymasa Polski - okoliczności, przebieg, konsekwencje (19531956), "Studia Prymasowskie" 2007, vol. 1.

Żaryn J., Dzieje Kościoła katolickiego w Polsce 1944-1989, Warszawa 2003.

Żaryn J., Kościót a władza w Polsce (1945-1950), Warszawa 1997.

\section{Online sources}

https://katalogi.bn.org.pl/discovery/search?query=any,contains,stefan\%20wyszy\%C5\%84ski\&tab=LibraryCatalog\&vid=48OMNIS_NLOP:48OMNIS_NLOP\&lang $=$ pl\&offset $=0$ 